\title{
Pengaruh ROE, CR, TATO, NPM Terhadap Harga Saham Pada Perusahaan Manufaktur Sub Customer Goods Yang Terdaftar Di Bursa Efek Indonesia
}

\author{
Bayu Wulandari \\ Universitas Prima Indonesia \\ bayuwulandari@unprimdn.ac.id \\ Imelda Kristiany Br Bukit \\ Universitas Prima Indonesia \\ Imelda.cz13@gmail.com
}

\author{
Irwanton Jaya Daeli \\ Universitas Prima Indonesia \\ irwantonjayadaeli1992@gmail.com \\ Winda Novita Sari Sibarani \\ Universitas Prima Indonesia \\ Winda_thebrave10@yahoo.com
}

\begin{abstract}
Abstrak
Penelitian ini bertujuan untuk menguji apakah Return on Equity, Current Ratio, Total Assets Turnover, Net Profit Margin memiliki pengaruh terhadap harga saham pada perusahaan manufaktur sub customer goods yang tercatat di Bursa Efek Indonesia. Jurnal ini merupakan jenis penelitian deskriptif kuantitatif, yang memakai data dari 43 perusahaan manufaktur sub customer goods yang tecatat di Bursa Efek Indonesia. Metode sampel yang digunakan dalam penelitian ini adalah purposive sampling dan diperoleh sebanyak 19 sampel. Data yang digunkaan adalah laporan keuangan dari masing-masing perusahaan sampel yang dipublikasikan melalui situs $w w w . i d x . c o . i d$. Adapun variabel yang berkaitan dengan penelitian ini adalah Return on Equity, Current Ratio, Total Assets Turnover, dan Net Profit Margin. Metode penelitian yang digunakan adalah metode uji asumsi klasik dan metode analisis regresi linear berganda. Hasil penelitian menunjukkan bahwa secara parsial Return on Equity, Current Ratio, Total Assets Turnover, Net Profit Margin tidak signifikan dan berpengaruh negatif terhadap harga saham, pada perusahaan sub customer goods yang tercatat di Bursa Efek Indonesia.
\end{abstract}

Kata Kunci: ROE, CR, TATO, NPM, Harga Saham.

\section{Pendahuluan}

\subsection{Latar Belakang Masalah}

Memasuki era globalisasi, dimana perkembangan teknologi dan informasi yang cepat, persaingan dalam dunia usaha menjadi begitu cepat. Satu-satunya jalan untuk tetap bertahan dan bersaing serta mempertahankan eksistensinya di dunia usaha yakni dengan terus tumbuh dan berkembang. Peranan pasar modal dewasa ini di rasakan sangat penting berkaitan dengan fungsi dari pasar modal itu sendiri yakni mempertemukan pihak yang membutukan dana dengan pihak yang ingin menanamkan modalnya pada pasar modal. Salah satu unsur dalam investasi di pasar modal adalah harga saham. Bursa efek Indonesia (BEI) merupakan pasar modal Indonesia yang mampu menyediakan data yang berupa data perdagangan saham. Pasar modal sangat penting bagi perekonomian suatu negara dikarenakan pasar modal menjalankan dua fungsi yani yang pertama sebagai sarana bagi pendanaan usahabagi perusahaan untuk mendapatkan dana dari investor yang kedua pasar modal menjadi sarana bagi masyarakat untuk berinvestasi pada instrument keuangan seperti obligasi, saham, reksa dana. Masyarakat menempatkan dana sebagai karakteristik meraih keuntungan serta resiko masing-masing instrument.

Kinerja perusahaan dapat kita lihat dari laba operasional, laba bersih persaham dan rasiorasio keuangan yang menunjukkan kemampuan manajemen dalam mengelola perusahaan. Rasio keuangan yang dapat digunakan untuk mengukur kinerja perusahaan diantaranya yaitu rasio likuiditas, rasio aktivitas, rasio solvabilitas, rasio profitabilitas.

Current ratio (CR) merupakan salah satu yang termasuk dalam rasio likuiditas. Current Ratio (CR) adalah dimana suatu perusahaan dapat memenuhi kewajiban jangka pendeknya.

Return on Equity (ROE) termasuk dalam pengukuran profitabilitas. Return on Equity (Roe) 
adalah kemampuan suatu perusahaan dalam menghasilkan laba yang didapat dari investasi pemegang saham disuatu perusahaan, ROE merupakan cara untuk para investor mengetahui seberapa efisien suatu perusahaan mengelola uang yang para investor investasikan untuk menghasilkan laba bersih.

Pengukuran Net Profit Margin (NPM) dilihat dengan membagi laba bersih terhadap

Tabel 1.1 Tabel Fenomena

Current ratio (CR), Return on Equity (Roe), Total Asset Turnover (TATO), Net Profit Margin (NPM) pada perusahaan Customer Goods yang terdaftar di BEI

\begin{tabular}{|l|l|l|l|l|l|l|}
\hline $\begin{array}{c}\text { Kode } \\
\text { Emiten }\end{array}$ & Tahun & Laba Bersih (ROE) & $\begin{array}{l}\text { Hutang Lancar } \\
\text { Jangka Pendek } \\
\text { (CR) }\end{array}$ & Penjulan Bersih (NPM) & \multicolumn{1}{l|}{ Total Aset (TATO) } \\
\hline CINT & 2015 & 36.575 .844 .922 & 58.865 .969 .544 & 315.229 .890 .328 .000 & 382.807 .494 .765 .000 \\
\hline & 2016 & 23.756 .169 .548 & 61.704 .877 .496 & 327.426 .146 .630 .000 & 399.336 .626 .636 .000 & 338 \\
\hline & 2017 & 64.041 .340 .293 & 66.014 .779 .104 & 373.955 .852 .243 .000 & 476.577 .841 .605 .000 & 334 \\
\hline HMSP & 2015 & 10.335 .007 .000 .000 & 4.538 .674 .000 .000 & 89.069 .306 .000 .000 & 38.010 .724 .000 .000 & 94.000 \\
\hline & 2016 & 12.530 .201 .000 .000 & 6.428 .478 .000 .000 & 95.466 .657 .000 .000 & 42.508 .277 .000 .000 & 3.830 \\
\hline & 2017 & 12.483 .134 .000 .000 & 6.482 .969 .000 .000 & 99.091 .484 .000 .000 & 43.141 .063 .000 .000 & 4.730 \\
\hline WIIM & 2015 & 125.706 .275 .922 & 341.705 .551 .602 & 1.839 .419 .574 .956 .000 & 1.342 .700 .045 .391 .000 & 430 \\
\hline & 2016 & 95.950 .660 .578 & 293.711 .761 .060 & 1.685 .795 .530 .617 .000 & 1.353 .634 .132 .275 .000 & 440 \\
\hline & 2017 & 19.591 .392 .031 & 160.790 .695 .868 & 1.476 .427 .090 .781 .000 & 1.225 .712 .093 .041 .000 & 268 \\
\hline TCID & 2015 & 541.116 .516 .960 & 222.930 .621 .643 & 2.314 .889 .854 .074 & 2.082 .096 .848 .703 \\
\hline & 2016 & 150.724 .362 .762 & 223.305 .151 .868 & 2.526 .776 .164 .168 & 2.185 .101 .038 .101 \\
\hline & 2017 & 157.605 .162 .569 & 259.806 .845 .843 & 2.706 .394 .847 .919 & 2.361 .807 .189 .430 \\
\hline
\end{tabular}

Sumber : Laporan Keuangan Publikasi BEI

Berdasarkan Table 1.1 diatas dapat dilihat bahwa perusahaan PT. Chitose Internasional Tbk mengalami kenaikan laba bersih dari tahun 2016 ke 2017 sebesar Rp. 40.285.170.745 sedangkan harga saham saham mengalami penurunan dari Rp 338 pada tahun 2016 menjadi Rp. 334 ditahun 2017 yang dimana seharusnya harga saham mengalami kenaikan karena meningkatnya Laba Bersih.

Pada perusahaan PT. Hanjaya Mandala Sampoerna Tbk (HMSP) mengalami peningkatan pada hutang lancar jangka pendek dari tahun 2016 ke 2017 sebesar Rp. 54.491.000.000 sedangkan harga saham mengalami peningkatan harga dari Rp. 3.830 ditahun 2016 menjadi Rp. 4.730 ditahun 2017 yang dimana seharusnya harga saham mengalami penurunan karena meningkatnya hutang lancar janga panjang.

Pada perusahaan PT. Wismilak Inti Makmur Tbk (WIIM) mengalami kelemahan pada Penjualan bersih di tahun 2015 ke 2016 sebesar Rp. 153.624.044.339.000, sedangkan harga saham mengalami peningkatan dari Rp. 430 ditahun 2015 menjadi Rp. 440 di tahun 2016 yang dimana seharusnya harga saham mengalami penurunan dikarenakan menurunnya total Penjualan bersih. penjualan bersih. Laba bersih sendiri dihitung sebagai hasil pengurangan antara laba sebelum pajak penghasilan dengan beban pajak penghasilan.

Pengukuran Total Asset Turnover (TATO) berfungsi untuk melihat sejauh mana suatu perusahaan mampu dalam menciptakan penjualan menggunakan seluruh asset yang dimiliki. 
Debt To Equity Ratio berpengaruh negative dan signifikan terhadap harga saham perusahaan pertambangan yang terdapat di BEI periode 2011-2015, Return On Equity berpengaruh positif dan signifikan terhadap harga saham perusahaan pertambangan yang terdaftar di BEi periode 2011-2015, Net Profit Margin berpengaruh positif dan signifikan terhadapa harga saham perusahaan pertambangan yang terdapat di BEI periode 2011-2015, Debt to Equity Ratio, Retun On Equity dan Net Profit Margin secara simultan berpengaruh signifikan terhadap harga saham perusahaan pertambangan yang terdaftar di BEI periode 2011-2015, (Ramadhani \& Pustikaningsih, 2017)

Hasil menunjukan EPS dan MVA secara parsial berpengaruh positif terhadap harga saham. Hasil pengujian berbeda untuk variabel DER, ROA, dan Roe secara parsial tidak berpengaruh terhadap harga saham. (Utami \& Darmawan, 2018)

\section{Landasan Teori}

\subsection{Teori Pengaruh}

Analisis rasio keuangan adalah kegiatan untuk menganalisis laporan keuangan dengan cara membandingkan satu akun dengan akun yang lainnya pada laporan keuangan, perbandingan tersebut bisa antar akun dalam laporan keuangan neraca atau pun rugi laba (Sujarweni, 2017). Berikut penjelasan rasio atas rasio tersebut:

\subsection{Return on Equity (ROE)}

Return on Equity (ROE) adalah suatu penilaian dari penghasilan yang tersedia bagi suatu perusahaan baik itu saham biasa maupun saham preferen atas modal yang mereka investasikan di dalam perusahaan (Syamsuddin , 2016)

Rasio Return on Equity (ROE) dapat dikatakan dengan laba atas equity rasio ini mengkaji sejauh mana suatu perusahaan mempergunakan sumber daya yang dimiliki untuk mampu menghasilkan laba atas equitas. (Fahmi, 2018)

Teori pengaruh Return on Equity (ROE) terhadap harga saham adalah Hasil pengembalian ekuitas atau return on equity atau rentabilitas modal sendiri adalah rasio untuk mengukur laba bersih sesudah pajak dengan modal sendiri, rasio ini menunjukan efisiensi penggunaan modal sendiri semakin tinggi rasio ini makan akan semakin bagus. Artinya posisi pemilik perusahaan semakin kuat demikian pula dengan sebaliknya (Kasmir, 2019).

Cara untuk mengukur Return on Equity (ROE) yakni dengan :

\section{Return On Equity :Laba Bersih Equitas}

\subsection{Current Rasio (CR)}

Current Ratio (CR) ialah ukuran keahlian suatu perusahaan untuk membayar liabilitas jangka pendek dari asset-aset jangka pendek yang dimilikinya. (Mowen, Hansen, \& Heitger, 2017)

Teori pengaruh Current Rasio (CR) terhadap harga saham menurut (Fahmi, 2018). Current Rasio (CR) ialah ukuran yang umum digunakan atas solvensi jangka pendek, kemampuan suatu perusahaan memenuhi kebutuhan utang ketika jatuh tempo, semakin meningkat jumlah (kelipatan) aktiva lancar terhadap kewajiban lancar maka semakin meningkat keyakinan bahwa kewajiban lancar tersebut akan dibayar.

Untuk mencari rasio lancar atau current rasio dapat menggunakan rumus sebagai berikut:

Current Rasio: Total Aset Lancar (Current Asset) Kewajiban Lancar (Current Liabities)

\subsection{Total Assets Turnover (TATO)}

Total Asset Turnover (TATO) merupakan kemampuan pendapatan yang tertahan dalam keseluruhan asset berputar dalam periode tertentu atau kemapuan modal yang di investasikan dalam menghasilkan pendapatan (Sujarweni, 2017).

Teori pengaruh terhadap total assets turnover (TATO) total assets turnover menunjukkan tingkat efisiensi penggunaan keseluruhan aktiva perusahaan perusahaan di dalam menghasilkan volume penjualan tertentu, (Syamsuddin , 2016). Semakin tinggi ratio total assets turnover berarti semakin efisien penggunaan keseluruhan aktiva di dalam menghasilkan penjualan. Dengan kata lain, jumlah asset yang sama dapat memperbesar volume penjualan apabila total assets turnover ditingkatkan atau diperbesar. Total assets turnover ini penting bagi para kreditur dan pemilik perusahaan, tetapi akan lebih penting bagi lagi manajemen perusahaan, karena hal ini menunjukkan efisien tidaknya penggunaan seluruh aktiva di dalam perusahaan.

Berikut rumus yang digunakan untuk mencari rasio perputaran total asset.

Total Asset Turnover : Penjualan Bersih Total Aset

\subsection{Net Profit Margin (NPM)}

Net Profit Margin (NPM) merupakan rasio untuk mengukur kemampuan perusahaan dalam 
menghasilkan laba bersih dari penjualan yang dilakukan perusahaan, rasio ini mencerminkan efisiensi seluruh bagian yakni produksi, personalia, pemasaran, dan keuangan yang ada dalam perusahaan (Sudana, 2015)

Teori pengaruh terhadap Net Profit Margin (NPM) merupakan rasio yang digunakan untuk mengukur laba bersih sesuah pajak lalu dibandingkan dengan volume penjualan (Sujarweni, 2017).

Margin laba bersih merupakan ukuran keuntungan dengan membandingkan antara laba setelah bunga dan pajak dibandingkan dengan penjualan, rasio ini menunjukkan pendapatan bersih perusahaan atas penjulan, (Kasmir, 2019).

Net Profit Margin: Laba Bersih

$$
\text { Penjualan Bersih }
$$

\subsection{Harga Saham}

Saham merupakan salah satu komoditas keuangan yang di perdagangkan di pasar modal yang paling popular. Investasi saham oleh investor diharapkan memberikan keuntungan saham sebagai surat berharga memiliki arti yakni saham memiliki nilai dan dapat diperjualbelikan, (Hadi, 2015).

Saham merupakan salah satu sekuritas yang diperdagangkan di busa efek, saham juga dapat di artikan sebagai penyertaan atau pemilikan seseorang atau badan usaha dalam suatu perusahaan, pemegang saham adalah pemilik dari sebuah perusahaan (Rodomi \& Ali, 2014)

Saham adalah tanda bukti penyertaan kepemilikan modal/dana pada suatu perusahaan. Kertas yang tercantum dengan jelas nilai nominal, nama perusahaan dan diikuti dengan hak dan kewajiban yang dijelaskan kepada setiap pemegangnya, saham juga merupakan persediaan yang siap untuk di jual. (Fahmi \& Irham, 2015).

\subsection{Kerangka Konseptual}

Adapun kerangka Konseptual dari penelitian ini dapat digambarkan sebagai berikut :

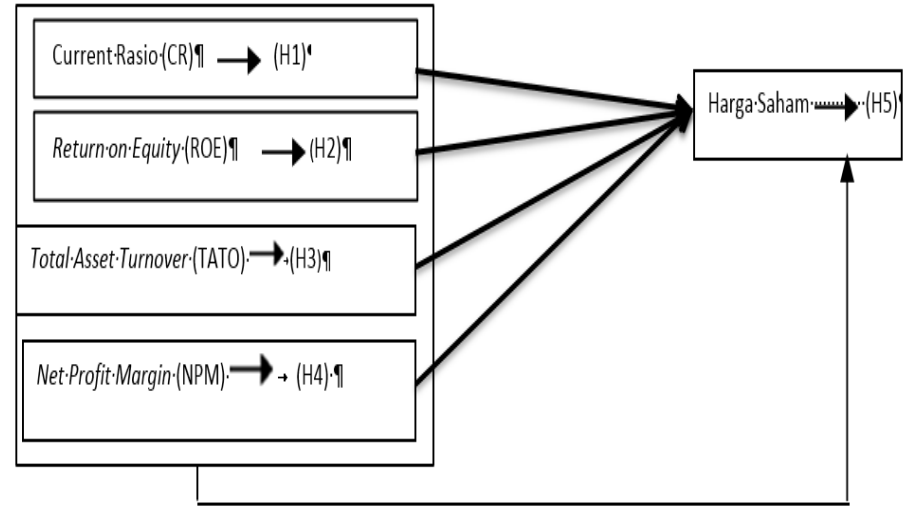

Hipotesis penelitian merupakan dugaan sementara terhadap masalah yang diajukan dan jawaban itu masih akan diuji secara empiris kebenarannya. Hipotesis dalam penelitiaan ini adalah :

H1: Current Rasio (CR) berpengaruh terhadap harga saham pada sector Customer Goods yang terdaftar di BEI periode 2015-2017.

$\mathrm{H} 2$ : Return on Equity (ROE) berpengaruh terhadap harga saham pada sector Customer Goods yang terdaftar di BEI periode 2015-2017.

H3: Total Asset Turnover (TATO) berpengaruh terhadap harga saham pada sector Customer Goods yang terdaftar di BEI periode 2015-2017.

H4: Net Profit Margin (NPM) berpengaruh terhadap harga saham pada sector Customer Goods yang terdaftar di BEI periode 2015-2017.

H5: Current Rasio (CR), Return on Equity (ROE), Total Asset Turnover (TATO), Net Profit Margin (NPM) berpengaruh terhadap harga saham pada sector Customer Goods yang terdaftar di BEI periode 2015-2017.

\section{Metodologi Penelitian \\ 3.1 Metode Penelitian}

Penelitian kuantitatif adalah penyelidikan tentang masalah kemasyarakatan ataupun kemanusiaan yang di dasarkan pada pengujian suatu teori yang tersusun atas variabel-variabel, diukur dengan bilangan-bilangan, dan di analisis dengan prosedur statistik bertujuan untuk menentukan apakah generalisasi-generalisasi prediktif dari teori tertentu yang di selidiki terbukti kebenarannya, (Trijono, 2015). Jenis data yang digunakan dalam jurnal ini adalah data sekunder. Data diperoleh melalui media internet seperti mencari informasi perusahaan yang tergolong dalam subsektor customer goods dengan mengakses www.sahamok.com (diolah oleh peneliti) serta mengakses www.idx.co.id (diolah oleh peneliti) 
untuk memperoleh laporan keuangan seperti neraca dan laporan laba rugi.

Varibel penelitian merupakan suatu simbol atau ciri khas dari objek, aktivitas yang memiliki variabel tertentu yang ditentukan tim peneliti sebagai pembelajaran sehingga mendapatkan keputusan dari penelitian tersebut, (Trijono, 2015). Dalam penelitian ini terdapat dua variabel penelitian yaitu variabel dependen dan variabel independen.

Variabel dependen dalam penelitian ini adalah harga saham. Harga saham yang tim peneliti terapkan dalam penelitian ini adalah harga pasar yang merupakan harga saham yang terdaftar di bursa efek Indonesia periode 2015 - 2017. Dalam penelitian ini, harga saham yang diterapkan tim peneliti merupakan harga penutupan (closing price), harga.

Pada penelitian ini variabel independen yang tim peneliti gunakan adalah Return on Equity (ROE), Current Rasio (CR), Total Assets Turnover (TATO), Net Profit Margin (NPM). Variabel independen sering juga disebut variabel bebas yang berpengaruh terhadap perubahannya atau timbulnya variabel terikat.

Sampel merupakan populasi yang telah dipilih. (Sanusi, 2012). Berikut sampel berdasarkan kriteria :

\subsection{Populasi dan Sampel}

Populasi merupakan seluruh elemen yang memperlihatkan ciri-ciri dalam membuat suatu kesimpulan, sehingga elemen tersebut memperlihatkan jumlah, sebaliknya ciri-ciri yang lainnya menunjukan sifat dari kelompok tersebut (Sanusi, 2012). Pada penelitian ini, tim peneliti menggunakan populasi pada perusahaan manufaktur sektor customer goods yang tercatat di Bursa Efek Indonesia periode 2015 - 2017.

Tabel 3.1 Sampel Berdasarkan Kriteria

\begin{tabular}{|l|l|}
\hline \multicolumn{1}{|c|}{ Deskripsi } & Jumlah \\
\hline $\begin{array}{l}\text { Perusahaan manufaktur sub } \\
\text { customer good yang tercatat di BEI } \\
\text { periode 2015-2017 }\end{array}$ & 43 \\
\hline $\begin{array}{l}\text { Perusahaan manufaktur sub } \\
\text { customer good yang tercatat di BEI } \\
\text { namun tidak menerbitkan laporan } \\
\text { keuangan periode 2015-2017 secara } \\
\text { berkala }\end{array}$ & \\
\hline
\end{tabular}

\begin{tabular}{|l|l|}
\hline $\begin{array}{l}\text { Perusahaan yang tidak memiliki } \\
\text { historical harga saham periode } \\
\text { 2015-2017 secara berkala }\end{array}$ & \\
\hline $\begin{array}{l}\text { Perusahaan manufaktur sub } \\
\text { customer good yang tercatat di BEI } \\
\text { yang mengalami kerugian periode } \\
2015-2017\end{array}$ & $(4)$ \\
\hline $\begin{array}{l}\text { Perusahaan yang digunakan } \\
\text { dalam penelitian }\end{array}$ & $\mathbf{1 9}$ \\
\hline
\end{tabular}

Berdasarkan proses seleksi tersebut, terdapat perusahaan yang akan menjadi sempel dengan periode 3 tahun, sehingga total keseluruhan sebanyak 57 observasi.

\subsection{Teknik Analisis Data}

Hubungan antara variabel terikat dengan variabel bebas dapat dilakukan dengan beberapa pengujian yakni :

\subsubsection{Uji Asumsi Klasik}

Uji asumsi klasikter diri dari uji multikolonieritas, ujiautokorelasi, uji heteroskedastisitas, uji normalitas, (Ghozali, 2019).

\section{Uji Multikolonieritas}

Uji Multikolonieritas berfungsi untuk menemukan apakah ada hubungan variabel bebas (independen). Model regresi yang baik seharusnya tidak terjadi korelasi diantara variabel independen. Jika variael independen saling berkorelasi, maka variabel-variabel ini tidak ortogonal.

\section{Uji Autokorelasi}

Uji Autokorelasi bertujuan mengujji apakah dalam model regresi linier ada kolerasi antara kesalahan penggangu pada periode $\mathrm{t}$ dengan kesalahan pengganggu pada peride $\mathrm{t}-1$ (sebelumnya). Jika terjadi korelasi, maka dinamakan ada problem autokorelasi.

\section{Uji Heteroskedastisitas}

Uji Heteroskedastisitas bertujuan menguji apakah dalam model regresi terjadi ketidaksamaan variance dari rasidual satu pengamatan ke pengamatan yang lain. Jika variance dari rasidual satu pengamatan ke pengamatan yang lain tetap, maka disebut homoskedastisitas dan jika berbeda disebut heteroskesdatisitas.

\section{Uji Normalitas}

Uji normalitas bertujuan untuk menguji apakah dalam model regresi, variable pengganggu atau residual memiliki distribusi normal. Ada dua cara 
untuk mendeteksi apakah residual berdistribusi normal atau tidak, yaitu dengan analisis grafik dan uji statistik.

\subsubsection{Uji Analisis Regresi Linier Berganda}

Regresi linier berganda pada dasarnya merupakan perluasan dari regresi linier sederhana, yaitu menambah jumlah variabel bebas yang sebelumnya hanya satu menjadi dua atau lebih variabel bebas, (Sanusi, 2012). Pada penelitian ini, ada tiga variabel bebas (independen) dan satu variabel terikat (dependen), Dengan demikian, regresi linier berganda dapat dirumuskan dengan:

$$
\mathrm{Y}=\mathrm{a}+\mathrm{b}_{1} \mathrm{X}_{1}+\mathrm{b}_{2} \mathrm{X}_{2}+\mathrm{b}_{3} \mathrm{X}_{3}+\mathrm{e}
$$

\section{$1 \quad$ Uji t}

Uji statistik t pada dasarnya menunjukkan seberapa jauh pengaruh satu variabel penjelas/independen secara individual dalam menerangkan variasi variabel dependen, (Ghozali, 2019). Hipotesis nol (H0) yang hendak diuji adalah apakah suatau parameter (bi) sama dengan nol, atau

$\mathrm{HO}: \mathrm{bi}=0$

Artinya apakah suatu variabel independen bukan merupakanpenjelas yang signifikan terhadap variabel dependen. Hipotesis alternatifnya (HA) parameter suatu variabel tidak sama dengan nol, atau:

$\mathrm{HA}: \mathrm{bi} \neq 0$

Artinya, variabel tersebut merupakan penjelas yang signifikan terhadap variabel dependen.

Cara melakukan uji t adalah sebagai berikut:

a. Quick look: bila jumlah degree of freedom (df) adlah 20 atau lebih, dan derajat kepercayaan sebesar $5 \%$, maka Ho yang menyatakan bi $=0$ dapat ditolak bila nilai t lebih dari 2(dalam nilai absolut). Dengan kata lain kita menerima hipotesis alternatif, yang menyatakan bahwa suatu variabel independen secara individual mempengaruhi variabel dependen.

Membandingkan nilai statistik $t$ dengan titik kritis menurut tabel. Apabila nilai statistik t hasil perhitungan lebih tinggi dibandingkan nilai t tabel, kita menerima hipotesis alternatif yang menyatakan bahwa suatu variabel independen secara individual mempengaruhi variabel dependen.

\section{Uji f}

Menurut Ghozaly (2019: 96) Uji F menguji joint hipotesia bahwa b1, b2 dan b3 secara simultan sama dengan nol, atau:

$\mathrm{HO}: \mathrm{b} 1=\mathrm{b} 2=\ldots \ldots \ldots=\mathrm{bk}=0$

$\mathrm{HA}: \mathrm{b} 1 \neq \mathrm{b} 2 \neq \ldots \ldots \ldots . \neq \mathrm{bk} \neq 0$
Uji hipotesis seperti ini dinamakan uji signifikansi secara keseluruhan terhadap garis regresi yang diobservasi maupun estimasi, apakah Y berhubungan linier terhadap X1, X2 dan X3. Untuk memenuhi hipotesis ini digunakan statistik $\mathrm{F}$ dengan kriteria pengambilan keputusan sebagai berikut:

a. Quick look: bila nilai F lebih besar daripada 4 maka Ho dapat ditolak pada derajat kepercayaan $5 \%$, dengan kata lain kita menerima hipotesis alternatif, yang menyatakan semua variabel independen secara serentak dan signifikan mempengaruhi variabel dependen.

b. Membandingkan nilai $\mathrm{F}$ hasil perhitungan dengan nilai $\mathrm{F}$ menurut tabel. Bila nilai $\mathrm{F}$ hitung lebih besar daripada nilai $\mathrm{F}$ tabel, maka Ho ditolak dan menerima HA.

\section{Hasil Dan Pembahasan \\ 4.1 Uji Asumsi Klasik}

Uji asumsi klasikter diri dari uji multikolonieritas, uji autokorelasi, uji heteroskedastisitas, uji normalitas, (Ghozali, 2019).

\subsubsection{Uji Multikolonieritas}

Uji Multikolonieritas berfungsi untuk menemukan apakah ada hubungan variabel bebas (independen). Model regresi yang baik seharusnya tidak terjadi korelasi diantara variabel independen. Jika variael independen saling berkorelasi, maka variabel-variabel ini tidak ortogonal.

Hasil pengolohan data dapat dilihat dari $\mathrm{Uji}$ Multikolonieritas dibawah ini :

Tabel 4.1 Uji Multikolonieritas

\begin{tabular}{llr|r} 
& \multicolumn{3}{c}{ Collinearity Statistics } \\
Model & Tolerance & VIF \\
\hline 1 & & & \\
\cline { 2 - 4 } & (Constant) & .031 & 31.950 \\
\cline { 2 - 4 } & LN_ROE & .201 & 4.976 \\
\cline { 2 - 4 } LN_CR & .029 & 34.456 \\
\hline LN_NPM & .166 & 6.009 \\
\hline LN_TATO & & \\
\hline
\end{tabular}

a. DependenVariabelL_HargaSaham

Berdasarkan table 4.1 diatas menunjukan nilai tolerance variabel CR, TATO berada diatas 0,10 dan tolerance variabel ROE dan NPM berada dibawah 0.10 sedangkan nilai VIF variabel CR dan TATO 
berada dibawah 10 dan variabel ROE NPM diatas 10. Batas tolerance value $>0,1$ atau VIF $<10$ maka terjadi multikolonieritas. Dengan demikian maka dari hasil uji multikolonieritas dapat diambil kesimpulan ROE dan NPM terjadi korelasi antar variabel indenpenden.

\subsubsection{Uji Autokorelasi}

Uji Autokorelasi bertujuan menguji apakah dalam model regresi linier ada korelasi antara error pada periode $t$ dengan error pada periode t-1 (sebelumnya) jika terjadi korelasi maka dinamakan ada masalah korelasi. Ada 3 cara untuk menguji autokorelasi :

a. Jika d lebih kecil dari dL atau lebih besar dari (4-dL) maka hipótesis 0 ditolak yang berarti terdapat autokorelasi.

b. Jika d terletak diantara dU dan (4-dU), maka hipótesis 0 diterima yang berarti tidak ada autokorelasi.

c. Jika d terletak antara $\mathrm{dL}$ dan dU atau diantara (4-dU) dan (4-dL) maka tidak menghasilkan kesimpulan yang pasti.

\section{Tabel 4.2 Uji Autokorelasi}

\begin{tabular}{|c|c|c|c|c|c|}
\hline Model & & $\begin{array}{r}R \\
\text { Square }\end{array}$ & $\begin{array}{r}\text { Adjusted } \\
\qquad \mathrm{R} \\
\text { Square }\end{array}$ & $\begin{array}{l}\text { Std. Error of } \\
\text { the Estimate }\end{array}$ & $\begin{array}{l}\text { Durbin- } \\
\text { Watson }\end{array}$ \\
\hline 1 & $.484^{\mathrm{a}}$ & .234 & .144 & 1.07342 & 1.875 \\
\hline
\end{tabular}

a. Predictors: (Constant), LN_TATO, LN_CR, LN_ROE, LN_NPM

b. Dependent Variable: LN_HARGASAHAmMDari tabel 4.2 di atas dapat disimpulkan bahwa nilai Durbin-Watson sebesar 1.875 dan nilai dU sebesar 1,7215 yang di dapat dari $\mathrm{n} ; \mathrm{k} 4$ (dU) dan nilai Durbin-Watsonnya terletak diantara dU dan (4-dU) karena nilai Durbin-Watsonnya lebih besar dari nilai dU yang dimana nilai Durbin-Watsonnya 1,875 dan nilai dU sebesar 1,7215 yang dimana artinya nilai $\mathrm{dW}$ lebih besar dari nilai dU dan nilainya kurang dari (4dU) maka tidak terjadi gejala autokorelasi.

\subsubsection{Uji Heteroskedastisitas}

Suatu model regresi yang baik adalah tidak terjadi heteroskedastisitas. Ada beberapa cara untuk menguji ada tidaknya situasi heteroskedastisitas dalam varian error terns untuk model regresi. Dalam penelitian akan digunakan metode chart (Diagram Scatterplot), dengan dasar pemikiran bahwa :
1. Jika ad apola tertentu seperti titik-titik (poinpoin), yang ada membentuk suatu pola tertentu yang beraturan (bergelombang, melebar, kemudian menyempit), maka terjadi heteroskedastisitas.

2. Jika ad apola yang jelas, serta titik-titik menyebar ketas dan dibawah nol pada sumbu y maka tidak terjadi heteroskedastisitas.

$$
\text { Scatterplot }
$$

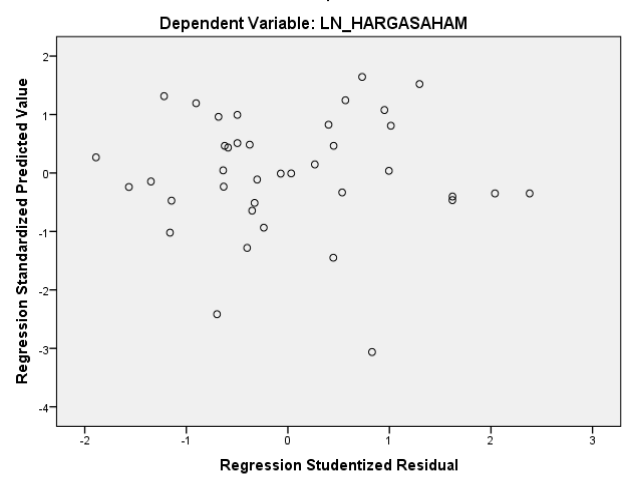

\section{Gambar 4.1 Uji Heteroskedastisitas}

Berdasarkan gambar 4.1 diatas menunjukan scatterplot dapat disimpulkan bahwa tidak terjadi heteroskedastisitas pada model regresi.

\subsubsection{Uji Normalitas}

Uji normalitas bertujuan untuk menguji apakah dalam model regresi, variabel pengganggu atau residual memiliki distribusi normal. Untuk melihat normalitas residual dilakukan dengan melihat analisis grafik yaitu dengan melihat grafik histogram yang membandingkan antara data observasi dengan distribusi yang mendekati normal dan normal probability plot yang membandingkan distribusi kumulatif dari distribusi normal.

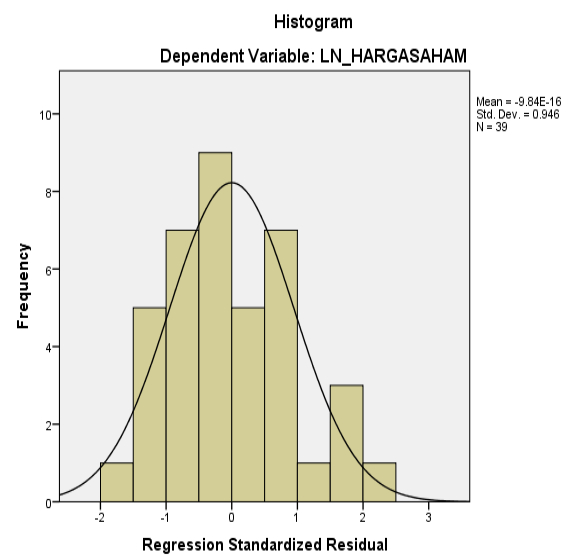

\section{Gambar 4.2 Uji Normalitas Histogram}

Grafik histogram pada gambar 4.2 diatas menunjukan garis kurva cenderung simetri (U) 
maka dapat dikatakan data distribusi normal kepada pola distribusi grafik histogram tidak melenceng ke kiri maupun ke kanan.

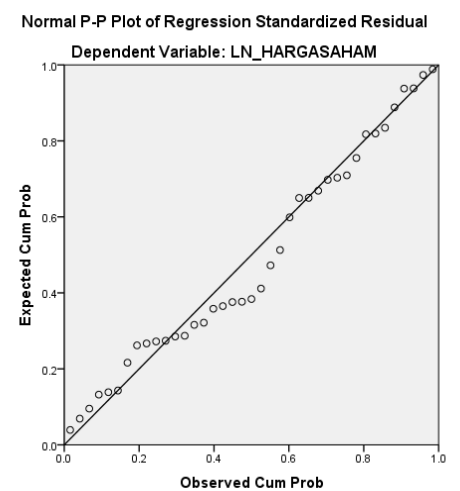

Gambar 4.3 Uji Normalitas P-P Plot

Grafik normalias P-P Plot pada gambar 4.3 diatas, terlihat titik-titik menyebar mendekati garis diagonal maka dapat dikatakan data berdistribusi normal. Selain analisi grafik histogram P-P Plot, untuk mengetahui apakah data berditribusi normal dapat digunakan uji statistik non-parametik kolmogorov smirnov jika nilai signifikasinya $>0,05$ maka dikatakan distribusi normal.

Tabel 4.3 Uji Normalitas kolmogorov smirnov

\begin{tabular}{|c|c|c|}
\hline \multicolumn{3}{|c|}{$\begin{array}{c}\text { One-Sample } \\
\text { Kolmogorov-Smirnov }\end{array}$} \\
\hline \\
\hline & & Residual \\
\hline $\mathrm{N}$ & & 39 \\
\hline Normal & & .0000000 \\
\hline Parameters ${ }^{a, b}$ & Mean & \\
\hline
\end{tabular}

\section{Tabel 4.4 Uji t}

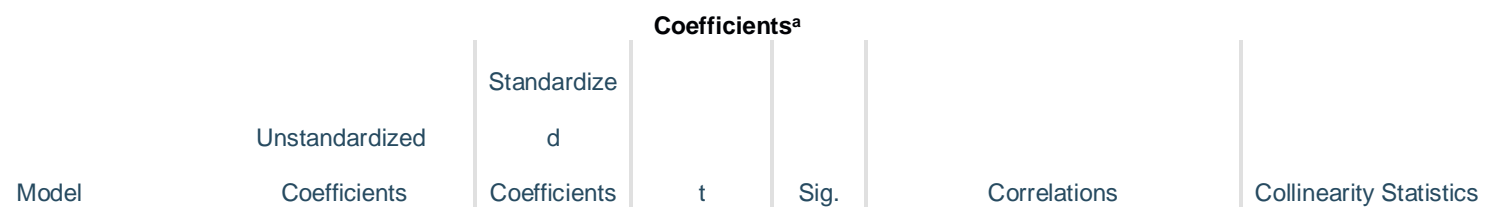

\begin{tabular}{llr} 
& Std. Deviation & 1.01535255 \\
\hline Most Extreme & & .136 \\
Differences & Absolute & .136 \\
& & \\
& Positive & \\
\cline { 2 - 3 } & Negative &. .071 \\
\hline Test Statistic & & .136 \\
\hline Asymp. Sig. (2-tailed) & $.069^{\mathrm{c}}$ \\
\hline
\end{tabular}

a. Test distribution is Normal.

b. Calculated from data.

Berdasarkan Tabel 4.3 di atas menunjukkan hasil uji statistic kolmogorov smirno dapat dikatakan bahwa variabel ROE (X1), CR (X2), NPM (X3), TATO (X4), dan Harga Saham (Y) sudah memenuhi syarat distribusi normal karena nilai signifikan sebesar $0,069>0,05$, dikatakan bahwa model regresi ini layak digunakan untuk

dianalisis lebih lanjut.

\subsection{Uji Analis Regresi Linier Berganda}

Regresi linier berganda pada dasarnya merupakan perluasan dari regresi linier sederhana, yaitu menambah jumlah variabel bebas yang sebelumnya hanya satu menjadi dua atau lebih variabel bebas, (Sanusi, 2012) Pada penelitian ini, ada tiga variabel bebas (independen) dan satu variabel terikat (dependen), Dengan demikian, regresi linier berganda dapat dirumuskan dengan:

\subsubsection{Uji t}

Uji statistic t pada dasarnya menunjukan seberapa jauh satu variabel penjelas/indenpenden secara individual dalam menerangkan variasi variabel dependen. Hipotesis nol (H0) yang akan diuji adalah apakah suatu parameter (bi) sama dengan nol. 


\begin{tabular}{|c|c|c|c|c|c|c|c|c|c|c|c|}
\hline & & B & Std. Error & Beta & & & Zero-order & Partial & Part & Tolerance & VIF \\
\hline \multirow[t]{5}{*}{1} & (Constant) & 8.141 & 1.532 & & 5.313 & .000 & & & & & \\
\hline & LN_ROE & 1.892 & 1.506 & 1.066 & 1.257 & .217 & .464 & .211 & .189 & .031 & 31.950 \\
\hline & LN_CR & .641 & .741 & .290 & .865 & .393 & .074 & .147 & .130 & .201 & 4.976 \\
\hline & LN_NPM & -1.068 & 1.506 & -.625 & -.709 & .483 & .417 & -.121 & -.106 & .029 & 34.456 \\
\hline & LN TATO & -1.286 & 1.703 & -.278 & -.755 & .455 & .077 & -.128 & -.113 & .166 & 6.009 \\
\hline
\end{tabular}

a. Dependent Variable: LN_HARGASAHAM

Dari table 4.4 menunjukan 0,217 > 0,05, hasil tersebut menunjukan ROE tidak signifikan terhadap harga saham. Hasil lain juga terlihat dari t hitung sebesar 1,257 lebih kecil dari t tabel yaitu sebesar 2,032245 . $t$ table dapat dirumuskan dengan $(\alpha / 2 ; n-$ $\mathrm{k}-1)$ yaitu 0,$025 ; 34$ dan hasil t menunjukkan 2,032245 . Hal ini menunjukkan tidak menerima hipotesis alternative yang menyatakan bahwa suatu variabel independen secara individual mempengaruhi variabel dependen. Pengujian terhadap CR juga dapat dilihat dari 0,393 >0,05 hal ini menunjukkan bahwa CR tidak signifikan terhadap Harga Saham. Sementara itu, t hitung sebesar 0,865 lebih kecil dari t table 2,032245 hal ini menunjukkan menolak hipotesis alternatif CR. Pengujian terhadap NPM dapat dilihat dari 0,483 > 0,05 hal ini menunjukkan bahwa NPM tidak signifikan terhadap Harga Saham yang dimana $t$ hitungnya sebesar $0,709<2,032245$ hal ini menunjukkan menolak hipotesis alternative. Sementara itu pengujian terhadap TATO menunjukkan 0,455>0,05 menunjukkan TATO tidak signifikan terhadap Harga Saham dimana t hitungnya sebesar $0,755<2,032245$.

\subsubsection{Uji f}

Uji $F$ digunakan untuk menunjukan apakah semua variabel indenpenden yang akan dimasudkan dalam model mempunyai pengaruh secara bersama-sama terhadap variabel dependen. Berdasarkan hasil pengolahan data dengan program SPSS maka di peroleh hasil sebagai berikut :

\section{\begin{tabular}{l|l|r|r|}
\hline & Total & 51.147 & 38 \\
\hline
\end{tabular} \\ a. Dependent Variable: LN_HARGASAHAM \\ b. Predictors: (Constant), LN_TATO, LN_CR, LN_ROE, LN_NPM}

Dari hasil pengujian statistic pada Tabel 4.5 dapat dilihat bahwa nilai signifikannya sebesar 0,054 dan lebih besar dari 0,05 , dan hasil dari f hitung menunjukan nilainya sebesar 2,597 yang lebih kecil dari $\mathrm{f}$ table sebesar 2,64. F tabel dapat dirumusakan dengan perhitungan $\mathrm{F}(\mathrm{k} ; \mathrm{n}-\mathrm{k})=\mathrm{F}(4 ; 35)$ dan setelah dilihat dari $\mathrm{F}$ tabel menunjukan bahwa hasilnya adalah 2,64. Dari hasil pengujian statistik tersebut variabel indenpenden ROE (X1),CR (X2), NPM (X3), TATO (X4) tidak berpengaruh terhadap variabel dependen Harga Saham (Y)

\subsection{Pembahasan Hasil Penelitian}

\subsubsection{Pengaruh ROE Terhadap Harga Saham}

Dari hasil pengujian secara parsial, dapat dilihat bahwa hasil pengujian statistik menunjukan $0,217>0,05$, hasil tersebut menunjukan ROE tidak signifikan terhadap harga saham. Hasil lain juga terlihat dari $\mathrm{t}$ hitung sebesar 1,257 lebih kecil dari t tabel yaitu sebesar 2,032245. t table dapat dirumuskan dengan $(\alpha / 2 ; \mathrm{n}-\mathrm{k}-1)$ yaitu 0,$025 ; 34$ dan hasil t menunjukkan 2,032245. Hal ini menunjukkan tidak menerima hipotesis alternative yang menyatakan bahwa suatu variabel independen secara individual mempengaruhi variabel dependen.

\subsubsection{Pengaruh CR Terhadap Harga Saham}

Dari hasil pengujian secara parsial, dapat dilihat bahwa hasil pengujian statistik CR dapat dilihat dari 0,393 >0,05 hal ini menunjukkan bahwa CR tidak signifikan terhadap Harga Saham. Sementara itu, t hitung sebesar 0,865 lebih kecil dari t table 2,032245 hal ini menunjukkan menolak hipotesis alternatif CR.

\begin{tabular}{|c|c|c|c|c|c|c|}
\hline Model & & $\begin{array}{r}\text { Sum of } \\
\text { Squares }\end{array}$ & Df & $\begin{array}{l}\text { Mean } \\
\text { Square }\end{array}$ & $\mathrm{F}$ & Sig. \\
\hline \multirow[t]{2}{*}{1} & Regression & 11.971 & 4 & 2.993 & 2.597 & \\
\hline & Residual & 39.176 & 34 & 1.152 & & \\
\hline
\end{tabular}
4.3.3 Pengaruh TATO Terhadap Harga Saham $.054^{\mathrm{b}} \quad$ Dari hasil pengujian secara parsial, dapat ditihat bahwa hasil pengujian statistic TATO menunjukkan 0,455 > 0,05 menunjukkan TATO tidak signifikan terhadap Harga Saham dimana t 
hitungnya sebesar0,755 $<2,032245$ hal ini menunjukkan menolak hipotesis alternative TATO.

\subsubsection{Pengaruh NPM Terhadap Harga Saham}

Dari hasil pengujian secara parsial, dapat dilihat bahwa hasil pengujian statistik NPM dilihat dari 0,483 > 0,05 hal ini menunjukkan bahwa NPM tidak signifikan terhadap Harga Saham yang dimana t hitungnya sebesar $0,709<2,032245$ hal ini menunjukkan menolak hipotesis alternative NPM.

\section{KESIMPULAN DAN SARAN}

\subsection{Kesimpulan}

Kesimpulan yang didapat dari hasil penelitian ini adalah :

1. ROE secara parsial berpengaruh negatif dan tidak signifikan terhadap harga saham pada perusahaan sub customer goods yang terdaftar di Bursa Efek Indonesia, sehingga hipótesis pertama $\left(\mathrm{H}_{1}\right)$ pada penelitian ini ditolak.

2. CR secara parsial berpengaruh negatif dan tidak signifikan terhadap harga saham pada perusahaan sub customer goods yang terdaftar di Bursa Efek Indonesia, sehingga hipótesis kedua $\left(\mathrm{H}_{2}\right)$ pada penelitian ini ditolak.

3. TATO secara parsial berpengaruh negatif dan tidak signifikan terhadap harga saham pada perusahaan sub customer goods yang terdaftar di Bursa Efek Indonesia, sehingga hipótesis ketiga $\left(\mathrm{H}_{3}\right)$ pada penelitian ini ditolak.

4. NPM secara parsial berpengaruh negatif dan tidak signifikan terhadap harga saham pada perusahaan sub customer goods yang terdaftar di Bursa Efek Indonesia, sehingga hipótesis keempat $\left(\mathrm{H}_{4}\right)$ pada penelitian ini ditolak.

\subsection{Saran}

1. Penelitian ini perlu di replikasikan dengan data periode yang lebih panjang serta meningkatkan variabel-variabel yang tidak tergolong dalam jurnal ini sehingga dapat memperbaiki hasilnya.

2. Bagi para investor hendaknya lebih memperhatikan informasi yang diberikan oleh perusahaan dalam menerik minatnya untuk menenamkan investasi, bukan hanya berdasarkan faktor-faktor yang ada diluar perusahaan.

\section{References}

Fahmi, I. (2015). Manajemen Investasi Edisi 2. Jakarta: Salemba Empat.
Fahmi, I. (2018). Pengantar Manajemen Keuangan. Bandung: Alfabeta.

Ghozali, I. (2019). Aplikasi Analisi Multivariete Dengan Program IBM SPSS 21. Semarang: Badan Penerbit-Undip.

Hadi, N. (2015). Pasar Modal Edisi Dua. Yogyakarta: Graha Ilmu.

Kasmir. (2019). Pengantar Manajemen Keuangan. Jakarta: Prenadamedia Group.

Mowen, M. M., Hansen, D. R., \& Heitger, D. L. (2017). Dasar-Dasar Akuntansi Manajerial. Jakarta: Salemba Empat.

Ramadhani, F. H., \& Pustikaningsih, A. (2017). Pengaruh Debt To Equity Ratio, Return On Equity Dan Net Profit Margin Terhadap Harga Saham Perusahaan Sektor Pertambangan Yang Terdapat Di Bursa Efek Indonesia Periode 2011-2015. Universitas Negeri Yogyakarta.

Rodomi, A., \& Ali, H. (2014). Manajeman Keuangan Modern. Jakarta: Mitra Wacana Media.

Sanusi, A. (2012). Metodologi Penelitian Bisnis. Jakarta: Salemba Empat.

Sudana, I. M. (2015). Manajemen Keuangan Perusahaan. Jakarta: Erlangga.

Sujarweni, V. W. (2017). Analisi Laporan Keuangan . Jogjakarta: Pustaka Baru Press.

Syamsuddin , L. (2016). Manajemen Keuangan Perusahaan. Jakarta: Rajawali.

Trijono, R. (2015). Metodologi Penelitian Kuantitatif. Depok: Timur Papas Sinarti.

Utami, M. R., \& Darmawan, A. (2018). Pengaruh DER, ROA, ROE, EPS Dan MVA Terhadap harga Saham Pada Indeks Saham Syariah Indonesia. Politeknik Negeri Batam. 
